\author{
젖소의 주요경제형질에 대한 국내생산 및 수입 정액의 능력비교 \\ 박병호 · 김시동 · 조광현 · 최재관 · 이영창 · 서강석 · A. Salces \\ 농촌진흥청 축산연구소
}

\title{
Performance Comparison of Local and Imported Dairy Semen Used in Rep. of Korea
}

\author{
B. H. Park, S. Kim, K. H. Cho, J. G. Choi, Y. C. Lee, K. S. Seo and A. Salces
}

National Livestock Research Institute, R.D.A.

\begin{abstract}
The data used in the study were taken from the national dairy genetic evaluation of bulls from 1986 up to 2001. It was conducted to compare the phenotypic performance and genetic merits in terms of production traits, linear traits and selection indexes of four types of dairy semen (Type I :semen from Korean proven bull, Type $\Pi$ :semen from proven bull imported by National Agricultural Cooperative Federation(NACF), Type III:semen imported from USA, Type IV:semen imported from Canada) used in Korea. The result of national dairy genetic evaluation was used to compare genetic merits. Type $\mathbb{I}$ was superior in the phenotypic performance of milk yield, milk fat and milk protein and was significantly different from Type I. Types of semen were not significantly different in fat when semen from bull born after 1991 were compared. Likewise, types of semen were not significantly different in the genetic merit for milk yield, milk fat, milk protein and milk protein \%. Moreso, for profit index (MFP) and Korean type production index (KTPI) it was not statistically different. However type I was superior in milk fat \% and was significantly different from other types. Type IV was superior in Final Score of conformation test (FS) and Udder Composite Index (UDC) and significantly different from Type I. When semen from bull born after 1991 were compared, types of semen were not significantly different in milk yield and milk protein, although type I was superior in milk fat, milk fat \%, milk protein \% and MFP and was significantly different from others. Moreover type III and type IV was superior in UDC and were significantly different from others.
\end{abstract}

(Key words: Genetic merit, Dairy semen)

\section{I. 서 론}

한 나라의 젖소를 개량하기 위해서는 유전자 원(정액 및 생축)을 수입하거나, 자국내에서 후대 검정을 실시하거나 또는 핵군을 형성하는 방법 등이 있다(Vargas와 van Arendonk, 2004). 그러나 정액 등을 계속 수입할 경우 수출국의 선발기준 에 종속되고 자국의 환경과 수입하는 유전자원
의 상호작용을 고려하기 어렵다. 그리하여 젖소 국제유전능력평가에서도 국가를 큰 환경효과로 분석하고 있다(Ceron-Munoz 등, 2004).

우리나라의 산유능력 검정은 1979년에 시작 을 하였고, 한국형 보증종모우를 선발하기 위 한 후대검정은 1987년에 시작하였다. 매년 15 두를 후대검정하여 한국형 보증종모우 1 2두 를 선발하고 있다. 초기에는 산유능력 검정 자

Corresponding author : B. H. Park, Animal Genetic Improvement Division, National Livestock Research Institute, Eoryong-ri Seonghwan-eup, Cheonan Si, Chungcheongnam-Do, Rep of KOREA 300-801 Tel : 041-580-3360, Fax : 041-580-3369, E-mail : bhpark70@rda.go.kr 
체가 활성화되지 않았으므로 많은 교배빈우를 확보하지 못하였으나 1997년 정부의 산유능력 검정 보조금 지급으로 산유능력 검정 두수가 급격히 증가하여 지금은 후보종모우를 300 두 이상의 교배 빈우에 교배한 후 후대검정을 하 여 한국형 보증종모우를 선발하고 있다.

위와 같이 선발한 한국형 보증종모우에서 생 산한 정액외에 국내에서 사용하고 있는 정액의 종류는 농협중앙회가 외국의 보증종모우를 직 접 수입하여 공급하는 정액과 미국 및 카다다 에서 수입하는 정액이 있다.

본 연구는 국내에서 사용한 정액을 네 분류 (한국형 보증종모우 정액, 농협 수입 보증종 모우 정액, 미국산 수입 정액 및 카나다산 수 입 정액)로 나누어 표현형 능력 및 유전능력 을 비교하여 앞으로의 한국형 보증종모우 선 발방향 설정을 위한 기초자료를 얻고자 실시 하였다.

\section{․․재료 및 방법}

\section{1. 분석자료}

국내에서 사용한 젖소 보증종모우의 정액을 1) 한국형 보증종모우 정액(Type I ), 2) 농협 수입 보증종모우 정액(Type ㅍ), 3) 미국산 수 입 정액(Type III), 4) 카나다산 수입 정액(Type IV) 등 네 분류로 나누었다. 한국형 보증종모우 정액이란 한국에서 후대검정 절차를 거쳐 선발 한 보증종모우에서 생산한 정액을 의미하고, 농협 수입 보증종모우 정액이란 농협중앙회가 미국 및 카나다에서 수입한 보증종모우로부터 생산한 정액을 의미하고, 미국산 수입 정액이 란 미국에서 제조한 후 수입한 정액을 의미하 며, 카나다산 수입 정액이란 카나다에서 제조 한 후 수입한 정액을 의미한다. 종모우의 생년 을 기준으로 1986년 이후의 종모우 정액 종류 별, 연도별 빈도수는 Table 1 과 같다.

\section{2. 통계분석}

본 자료를 분석하기 위하여 정액의 종류를
요인으로 한 일원 분산분석(one way analysis of variance)을 실시하였으며, 분산분석에서 유의성 이 인정된 경우 평균간 다중 검정을 실시하였는 데, 던칸의 다중 비교법(Duncan's multiple range test)을 이용하였다. 분석 프로그램으로 SAS 9.1 을 사용하였다(SAS, 1989).

Table 1. Number of records of the type of semen by birth year of proven bulls

\begin{tabular}{rrrrr}
\hline \multirow{2}{*}{$\begin{array}{c}\text { Birth } \\
\text { year }\end{array}$} & \multicolumn{4}{c}{ Type } \\
\cline { 2 - 5 } 1986 & $\mathrm{I}$ & $\mathbb{I}$ & $\mathrm{II}$ & $\mathrm{I}$ \\
\hline 1987 & & 6 & 36 & 11 \\
1988 & 3 & 6 & 33 & 7 \\
1989 & 4 & 7 & 49 & 8 \\
1990 & 1 & 2 & 35 & 9 \\
1991 & 2 & 3 & 28 & 19 \\
1992 & & 4 & 21 & 6 \\
1993 & & 3 & 18 & 7 \\
1994 & 3 & 3 & 26 & 126 \\
1995 & 2 & 4 & 37 & 9 \\
1996 & 2 & 6 & 34 & 5 \\
1997 & & 2 & 17 & \\
1998 & 1 & & & \\
1999 & 4 & 2 & & 1 \\
2000 & & & & \\
2001 & 2 & & 384 & 108 \\
\hline Total & 24 & 65 & & \\
\hline I: Senen & & & & \\
\hline
\end{tabular}

I : Semen from Korean proven bull, $\square$ : Semen from proven bull imported by NACF, III: Semen imported from USA, IV: Semen imported from Canada.

\section{III. 결과 및 고찰}

\section{1. 표현형 능력 비교}

보증종모우의 경우 유생산 능력을 직접 측정 할 수 없으므로 딸소의 평균을 이용하여 보증 종모우의 능력을 비교하였다. Table 2는 305일 보정 유량, 유단백량 및 유지량에 대한 비교 결과다. 
Table 2. Least-squares mean and standard error of milk yield, protein yield and fat yield

\begin{tabular}{ccccc}
\hline Semen Type & N & Milk yield(kg) & Milk Fat yield(kg) & Milk Protein yield(kg) \\
\hline \hline I & 24 & $7646.8^{\mathrm{bc}} \pm 179.6$ & $291.6^{\mathrm{ab}} \pm 7.8$ & $241.1^{\mathrm{b}} \pm 5.5$ \\
II & 65 & $7452.7^{\mathrm{c}} \pm 109.1$ & $278.4^{\mathrm{b}} \pm 4.7$ & $235.8^{\mathrm{b}} \pm 3.3$ \\
III & 384 & $8061.3^{\mathrm{a}} \pm 44.9$ & $296.2^{\mathrm{a}} \pm 1.9$ & $253.6^{\mathrm{a}} \pm 1.3$ \\
IV & 108 & $7964.8^{\mathrm{ab}} \pm 84.6$ & $295.5^{\mathrm{a}} \pm 3.7$ & $253.3^{\mathrm{a}} \pm 2.5$ \\
\hline
\end{tabular}

I : Semen from Korean proven bull, $\Pi$ : Semen from proven bull imported by NACF,

III: Semen imported from USA, IV: Semen imported from Canada.

abc Means in the same column with different superscripts $\operatorname{differ}(\mathrm{p}<0.05)$.

보증종모우 정액의 표현형 능력을 비교한 결 과 305일 유량의 경우 미국산 수입 정액이 $8,061.3 \mathrm{~kg}$ 으로 제일 우수하였고, 한국형 보증종 모우 정액은 카나다산 수입 정액과 통계적으로 유의한 차이가 없었다. 305일 유지량의 경우 미국산 수입 정액이 $296.2 \mathrm{~kg}$ 으로 제일 우수하 였지만, 카나다산 수입 정액 및 한국형 보증종 모우 정액과 통계적으로 유의한 차이가 없었 다. 305일 유단백량의 경우 미국산 수입 정액 이 $253.6 \mathrm{~kg}$ 으로 제일 우수하였고, 한국형 보증 종모우 정액 및 농협 수입 보증종모우 정액은 미국산 수입 정액 및 카나단산 수입 정액과 통 계적으로 유의한 차이를 보였다.

1997년 산유능력검정이 크게 늘었는데, 보증 종모우의 선발시 연령을 6 7세로 볼 경우 1997 년 이후 사용하기 시작한 정액의 능력을 비교 하기 위하여 생년을 기준으로 1991년 이후에 태어난 보증종모우의 305일 보정 유량, 유지량, 유단백량을 비교하였다.

1991년 이후에 태어난 보증종모우에서 생산
한 정액을 비교한 결과 305일 유량은 미국산 수입 정액이 $8419.6 \mathrm{~kg}$ 으로 가장 우수하였고, 한국형 보증종모우 정액은 미국산 및 카나다산 수입 정액과 유의한 차이를 보였다. 유지량의 경우 네 종류의 정액 모두 통계적으로 유의한 차이를 보이지 않았다. 유단백량의 경우 미국 산 수입 정액이 $262.8 \mathrm{~kg}$ 으로 가장 우수하였고, 한국형 보증종모우 정액은 미국산 및 카나다산 수입 정액과 유의한 차이를 보였다. 최근 한국 형 보증종모우 정액의 유량 및 유단백량 표현 형 능력은 미국산 수입 정액 및 카나다산 수입 정액과 비교하여 저조한 것으로 나타났다.

유량, 유지량 및 유단백량의 유전능력에 대 한 한국형 보증종모우 정액과 수입정액의 능력 은 통계적으로 유의한 차이가 없으나 수입 정 액의 표현형 능력이 우수한 것은 이러한 정액 의 가격이 고가이고 따라서 선별적으로 사용하 였을 가능성이 있고, 또한 자손도 특별한 관리 를 받았을 가능성이 있을 것으로 사료된다(Atagi 등, 1999; Weigel 1996).

Table 3. Least-squares mean and standard error of milk yield, protein yield and fat yield of semen from proven bull born after 1991

\begin{tabular}{crccc}
\hline Semen Type & $\mathrm{N}$ & Milk yield(kg) & Milk Fat yield(kg) & Milk Protein yield(kg) \\
\hline \hline I & 16 & $7804.7^{\mathrm{c}} \pm 171.6$ & $301.3 \pm 8.6$ & $245.7^{\mathrm{c}} \pm 5.7$ \\
II & 27 & $7999.1^{\mathrm{bc}} \pm 132.1$ & $301.3 \pm 6.6$ & $250.7^{\mathrm{bc}} \pm 4.4$ \\
III & 182 & $8419.6^{\mathrm{a}} \pm 50.9$ & $316.9 \pm 2.5$ & $262.8^{\mathrm{a}} \pm 1.7$ \\
IV & 65 & $8210.9^{\mathrm{ab}} \pm 85.1$ & $308.6 \pm 4.3$ & $258.3^{\mathrm{ab}} \pm 2.8$ \\
\hline
\end{tabular}

I : Semen from Korean proven bull, $\square$ : Semen from proven bull imported by NACF,

III: Semen imported from USA, IV: Semen imported from Canada.

abc Means in the same column with different superscripts $\operatorname{differ}(\mathrm{p}<0.05)$. 


\section{2. 유전능력 비교}

농촌진흥청 축산연구소에서 실시하고 있는 국가단위 젖소 유전능력평가 결과를 이용하여 보증종모우의 유전능력을 비교하였다.

305일 유량 유전능력의 경우 미국산 수입 정 액이 86.72로 우수하였으나 네 종류의 정액 사 이에 통계적으로 유의한 차이는 없었다. 유지 량, 유단백량 및 유단백율 각각 한국형 보증종 모우 정액, 카나다산 수입 정액, 한국형 보증종 모우 정액이 우수하였으나 네 종류의 정액 사 이에 통계적으로 유의한 차이는 없었다. 유지 율의 경우 한국형 보증종모우 정액이 0.0066 으 로 가장 우수하였고, 미국산 및 카나다산 수입 정액과 유의한 차이를 보였다.

보증종모우의 선형심사 최종점수(Final Score) 및 선발지수의 유전능력을 비교한 것을 Table 5 에 나타내었다.

선형심사 최종점수의 경우 한국형 보증종모 우 정액의 유전능력이 0.022로 가장 저조하였 으며, 가장 우수한 카나다산 수입 정액과 유의
한 차이를 보였다. 유방종합지수(UDC)도 선형 심사 최종점수와 마찬가지로 한국형 보증종모 우 정액의 유전능력이 0.257 로 가장 저조한 능 력을 보였으며, 나머지 정액의 유전능력과 유 의한 차이를 보였다. 카나다산 수입 정액의 경 우 선형심사 형질에 대하여 오랜 기간 선발을 한 결과로 이번 결과에서 우수한 성적을 보인 것으로 사료되었다(Miglior, 2004). 국내 보증종 모우 선발지수식인 체형능력종합지수(KTPI)에 선형심사 형질이 포함되었음에도 불구하고(축 산연구소, 2005), 한국형 보증종모우 정액의 유 전능력이 수입 정액과 비교하여 상대적으로 낮 은 것으로 보아 선형심사 형질에 대한 보정계 수 개발(송치은 등, 2002) 및 평가방법 개선 등 이 필요할 것으로 사료된다. 수익지수인 MFP (도창희, 1995) 형질의 경우 한국형 보증종모우 정액이 75.63의 능력을 보였으나 네 종류의 정 액 사이에 통계적으로 유의한 차이는 없었다. 한국형 보증종모우 선발의 주된 기준이 되는 KTPI의 경우 네 종류의 정액 사이에 통계적으 로 유의한 차이는 없었다.

Table 4. Least-squares mean and standard error of production trait's breeding value

\begin{tabular}{crccccr}
\hline $\begin{array}{c}\text { Semen } \\
\text { Type }\end{array}$ & $\mathrm{N}$ & Milk yield(kg) & $\begin{array}{c}\text { Milk Fat } \\
\text { yield(kg) }\end{array}$ & Milk Fat \% & $\begin{array}{c}\text { Milk Protein } \\
\text { yield(kg) }\end{array}$ & Milk Protein \% \\
\hline \hline I & 24 & $41.96 \pm 36.35$ & $1.74 \pm 1.52$ & $0.0066^{\mathrm{a}} \pm 0.0192$ & $1.47 \pm 1.04$ & $0.0065 \pm 0.0072$ \\
II & 65 & $25.99 \pm 22.08$ & $0.57 \pm 0.92$ & $-0.0061^{\mathrm{ab}} \pm 0.0117$ & $1.08 \pm 0.63$ & $0.0017 \pm 0.0044$ \\
III & 384 & $86.72 \pm 9.08$ & $0.45 \pm 0.38$ & $-0.0393^{\mathrm{bc}} \pm 0.0048$ & $2.57 \pm 0.26$ & $-0.0062 \pm 0.0018$ \\
IV & 108 & $84.56 \pm 17.13$ & $-0.15 \pm 0.71$ & $-0.0442^{\mathrm{c}} \pm 0.0090$ & $2.71 \pm 0.49$ & $-0.0013 \pm 0.0034$ \\
\hline
\end{tabular}

I : Semen from Korean proven bull, $\square$ : Semen from proven bull imported by NACF,

III: Semen imported from USA, IV: Semen imported from Canada.

abc Means in the same column with different superscripts $\operatorname{differ}(\mathrm{p}<0.05)$.

Table 5. Least-squares mean and standard error of final score of conformation test and selection indexes

\begin{tabular}{crccrc}
\hline Semen Type & \multicolumn{1}{c}{ N } & Final Score & UDC & MFP & KTPI \\
\hline \hline I & 24 & $0.022^{\mathrm{b}} \pm 0.220$ & $0.257^{\mathrm{b}} \pm 0.119$ & $75.63 \pm 77.25$ & $651.6 \pm 46.92$ \\
I & 65 & $0.220^{\mathrm{ab}} \pm 0.133$ & $0.486^{\mathrm{a}} \pm 0.072$ & $27.67 \pm 46.94$ & $655.8 \pm 28.51$ \\
III & 384 & $0.300^{\mathrm{ab}} \pm 0.055$ & $0.659^{\mathrm{a}} \pm 0.029$ & $-18.21 \pm 19.31$ & $693.5 \pm 11.73$ \\
IV & 108 & $0.578^{\mathrm{a}} \pm 0.103$ & $0.700^{\mathrm{a}} \pm 0.056$ & $-39.69 \pm 36.41$ & $703.5 \pm 22.12$ \\
\hline
\end{tabular}

I : Semen from Korean proven bull, $\Pi$ : Semen from proven bull imported by NACF, III: Semen imported from USA, IV: Semen imported from Canada, UDC : Udder Composite Index, MFP : Profit index, KTPI : Korean Type Production index.

ab Means in the same column with different superscripts $\operatorname{differ}(\mathrm{p}<0.05)$. 
국내에서 사용한 정액의 최근 경향을 알아보 기 위하여 1991년 이후에 태어난 보증종모우로 부터 생산한 정액을 비교하였다.

1991년 이후 태어난 보증종모우의 유전능력 을 비교해 본 결과 유량의 경우 네 종류의 정 액 사이에 통계적으로 유의한 차이가 없었으 며, 유지량 및 유지율의 경우 한국형 보증종모 우 정액이 3.61 및 0.0279로 가장 우수하였고, 나머지 보증종모우 정액과 유의한 차이를 보였 다. 전체를 대상으로 한 비교와 달리 1991년 이후 태어난 보증종모우를 비교하였을 때 한국 형 보증종모우가 우수한 성적을 보인 것은 유 지율이 유대 결정에 중요한 요인인 국내 환경 에서 진행한 후대검정 및 보증종모우 선발 과 정이 주요 원인인 것으로 사료된다. 유단백량 의 경우 네 종류의 정액 사이에 유의한 차이가 없었으며, 유단백율의 경우 한국형 보증종모우 가 0.0104로 우수하였고, 나머지 정액과 유의한 차이를 보였다.

1991년 이후에 태어난 보증종모우의 선형심
사 최종점수 및 선발지수의 유전능력을 비교한 것을 Table 7에 나타내었다.

1991년 이후 태어난 보증종모우 선형심사 최 종점수의 유전능력을 보면 카나다산 수입 정액 이 0.373 으로 가장 좋은 성적을 보였으나, 한국 형 보증종모우 정액과 유의한 차이는 없었다. 유방종합지수의 유전능력은 카나다산 수입 정 액이 가장 우수하였고, 한국형 보증종모우 정 액 및 농협 수입 보증종모우 정액과 유의한 차 이를 나타내었다. 수익지수인 MFP 형질의 경 우 한국형 보증종모우 정액이 가장 우수하였 고, 나머지 정액과 유의한 차이를 나타내었다. $\mathrm{KTPI}$ 의 경우 한국형 보증종모우 정액이 707.13 으로 가장 우수하였고, 농협 수입 보증종모우 정액은 가장 낮은 성적을 보였다.

최근에 선발한 한국형 보증종모우 정액의 유 전능력은 미국산 및 카나다산 수입 정액의 유 전능력과 비교하여 선형심사 형질을 제외하고 는 우수하거나 통계적으로 유의한 차이가 없었 다. 그에 비하여 농협 수입 보증종모우 정액의

Table 6. Least-squares mean and standard error of production trait's breeding value of semen from proven bull born after 1991

\begin{tabular}{crccccr}
\hline $\begin{array}{c}\text { Semen } \\
\text { Type }\end{array}$ & N & Milk yield(kg) & $\begin{array}{c}\text { Milk Fat } \\
\text { yield(kg) }\end{array}$ & Milk Fat \% & $\begin{array}{c}\text { Milk Protein } \\
\text { yield(kg) }\end{array}$ & Milk Protein \% \\
\hline \hline I & 16 & $50.60 \pm 46.98$ & $3.61^{\mathrm{a}} \pm 2.06$ & $0.0279^{\mathrm{a}} \pm 0.0259$ & $2.14 \pm 1.36$ & $0.0104^{\mathrm{a}} \pm 0.0084$ \\
I & 27 & $16.47 \pm 36.16$ & $-2.04^{\mathrm{b}} \pm 1.58$ & $-0.0286^{\mathrm{b}} \pm 0.0199$ & $0.90 \pm 1.05$ & $-0.0066^{\mathrm{b}} \pm 0.0065$ \\
II & 182 & $61.39 \pm 13.93$ & $-1.61^{\mathrm{b}} \pm 0.61$ & $-0.0552^{\mathrm{b}} \pm 0.0076$ & $1.86 \pm 0.40$ & $-0.0076^{\mathrm{b}} \pm 0.0025$ \\
$\mathrm{IV}$ & 65 & $60.95 \pm 23.31$ & $-1.71^{\mathrm{b}} \pm 1.02$ & $-0.0522^{\mathrm{b}} \pm 0.0128$ & $1.84 \pm 0.67$ & $-0.0070^{\mathrm{b}} \pm 0.0042$ \\
\hline
\end{tabular}

I : Semen from Korean proven bull, $\square$ : Semen from proven bull imported by NACF,

III: Semen imported from USA, IV: Semen imported from Canada.

ab Means in the same column with different superscripts $\operatorname{differ}(\mathrm{p}<0.05)$.

Table 7. Least-squares mean and standard error of final score of conformation test and selection indexes of semen from proven bull born after 1991

\begin{tabular}{crccccc}
\hline $\begin{array}{c}\text { Semen } \\
\text { Type }\end{array}$ & N & \multicolumn{2}{c}{ Final Score } & UDC & MFP & KTPI \\
\hline \hline I & 16 & $0.067^{\mathrm{ab}} \pm 0.263$ & $0.370^{\mathrm{b}} \pm 0.149$ & $179.52^{\mathrm{a}} \pm 108.20$ & $707.13^{\mathrm{a}} \pm 59.93$ \\
I & 27 & $-0.363^{\mathrm{b}} \pm 0.203$ & $0.391^{\mathrm{b}} \pm 0.115$ & $-94.33^{\mathrm{b}} \pm 83.29$ & $565.43^{\mathrm{b}} \pm 46.14$ \\
II & 182 & $-0.128^{\mathrm{ab}} \pm 0.078$ & $0.610^{\mathrm{ab}} \pm 0.044$ & $-107.40^{\mathrm{b}} \pm 32.08$ & $618.44^{\mathrm{ab}} \pm 17.77$ \\
IV & 65 & $0.373^{\mathrm{a}} \pm 0.130$ & $0.715^{\mathrm{a}} \pm 0.074$ & $-112.57^{\mathrm{b}} \pm 53.68$ & $653.19^{\mathrm{ab}} \pm 29.73$ \\
\hline
\end{tabular}

I : Semen from Korean proven bull, $\Pi$ : Semen from proven bull imported by NACF,

III: Semen imported from USA, IV: Semen imported from Canada, UDC : Udder Composite Index, MFP : Profit index, KTPI : Korean Type Production index.

ab Means in the same column with different superscripts $\operatorname{differ}(\mathrm{p}<0.05)$. 
유전능력은 미국산 정액의 유전능력과 비교해 볼 때 통계적으로 유의한 차이가 없었으며, 카 나다산 수입 정액의 유전능력과 비교해 보면 생산형질 및 선발지수에서는 유의한 차이가 없 었으나 선형심사 형질에서는 유의한 차이를 나 타내었다. 이것으로 보아 농협이 국내의 젖소 정액 공급을 위하여 수입하고 있는 보증종모우 물량을 줄여나가고, 국내에서 후대검정을 실시 하는 한국형 보증종모우 선발을 확대해야 할 것으로 사료된다.

\section{IV. 요 약}

국내에서 사용한 젓소 정액을 네 가지(한국형 보증종모우 정액, 농협 수입 보증종모우 정액, 미국산 수입 정액, 카나다산 수입 정액)로 분류 하여 표현형 능력 및 유전능력을 비교하였다. 유전능력의 경우 농촌진흥청 축산연구소에 수 행하고 있는 국가단위 젖소유전능력평가 결과 를 이용하였다. 유량, 유지량 및 유단백량의 표 현형 능력의 경우 미국산 수입 정액이 가장 우 수하였고, 한국형 보증종모우 정액은 미국산 수입 정액과 유의한 차이를 보였다. 1991년 이 후 태어난 보증종모우의 경우 유지량은 네 종 류의 정액 사이에 유의한 차이가 없었다. 유량, 유지량, 유단백량, 유단백율 유전능력의 경우 네 종류 사이에 유의한 차이가 없었으며, 유지 율의 경우 한국형 보증종모우 정액이 가장 우 수하였다. 선형심사 최종점수 및 유방종합지수 의 경우 카나다산 수입정액이 가장 우수하였으 며, 한국형 보증종모우 정액과 유의한 차이를 보였다. MFP 및 KTPI의 경우 네 종류 사이에 유의한 차이가 없었다. 1991년 이후에 태어난 보증종모우의 유량 및 유단백량의 경우 네 종 류 사이에 유의한 차이가 없었으나, 유지량, 유 지율 및 유단백율의 경우 한국형 보증종모우 정액이 가장 우수하였고, 나머지 정액과 유의 한 차이를 보였다. 선형심사 최종점수의 경우 한국형 보증종모우 정액, 미국산 수입정액 및 카나다산 수입정액 사이에 통계적으로 유의한 차이가 없었다. 유방종합지수의 경우 카나다산 수입정액이 가장 우수하였고, 한국형 보증종모
우 정액과 유의한 차이가 났다. $\mathrm{MFP}$ 의 경우 한국형 보증종모우 정액이 가장 우수하였고, 나머지 정액과 유의한 차이를 보였다. $\mathrm{KTPI}$ 의 경우 한국형 보증종모우 정액, 미국산 수입정 액 및 카나다산 수입정액 사이에 통계적으로 유의한 차이가 없었다.

\section{$\mathrm{V}$. 인 용 문 헌}

1. Atagi, Y., Jansen, G. B. and Schaeffer, L. R. 1999. Impact of Japanese imported semen evaluations on international bull evaluations. Interbull Bulletin 22, pp. 52-56.

2. Ceron-Munoz, M. F., Tonhati, H., Costa, C. N., Rojas-Sarmiento, D. and Echeverri, D. M. 2004. Factors that Cause Genotype by Environment Interaction and Use of Multiple-Trait Herd-Cluster Model for Milk Yield of Holstein Cattle from Brazil and Colombia. J. Dairy Sci. 87:2687-2692.

3. Miglior, F. 2004. Overview of different breeding objectives in various countries. Proc. 11th. WHFF Meeting. Session 4:7-11.

4. SAS. 1989. SAS/STAT User's Guide. Version 6. SAS Inst., Inc., Cary, NC.

5. Vargas, B. and van Arendonk, J. A. M. 2004. Genetic Comparison of Breeding Schemes Based on Semen Importation and Local Breeding Schemes : Framework and Application to Costa Rica. J. Dairy Sci. 87:1496-1505.

6. Weigel, K. A. 1996. Impact of second-country data of foreign bulls on international evaluations of dairy bulls. J. Dairy Sci. 79, 900.

7. 도창희. 1995. 우리나라 젖소 유전능력의 경제효 과와 유대체계에 대한 고찰. 한국축산학회지 37 : 583-588.

8. 송치은, 상병찬, 도창희. 2002. 국내 홀스타인젖 소의 선형심사에 대한 보정계수 개발. 한국동물 자원과학학회지. 44(1):1-12

9. 축산연구소. 2004. 가축개량관련자료.

10. 축산연구소. 2005. 젖소유전능력평가보고서.

(접수일자 : 2005. 11. 3. / 채택일자 : 2006. 1. 4.) 